Connell, Cara, Marciniak, Ruth, Carey, Lindsey and McColl, Julie (2019) 'Customer engagement with websites: a transactional retail perspective. European Journal of Marketing.

Downloaded from: http://ray.yorksj.ac.uk/id/eprint/3622/

The version presented here may differ from the published version or version of record. If you intend to cite from the work you are advised to consult the publisher's version: https://www.emeraldinsight.com/doi/full/10.1108/EJM-10-2017-0649

Research at York St John (RaY) is an institutional repository. It supports the principles of open access by making the research outputs of the University available in digital form. Copyright of the items stored in RaY reside with the authors and/or other copyright owners. Users may access full text items free of charge, and may download a copy for private study or non-commercial research. For further reuse terms, see licence terms governing individual outputs. Institutional Repository Policy Statement

\title{
RaY
}

Research at the University of York St John

For more information please contact RaY at ray@yorksj.ac.uk 


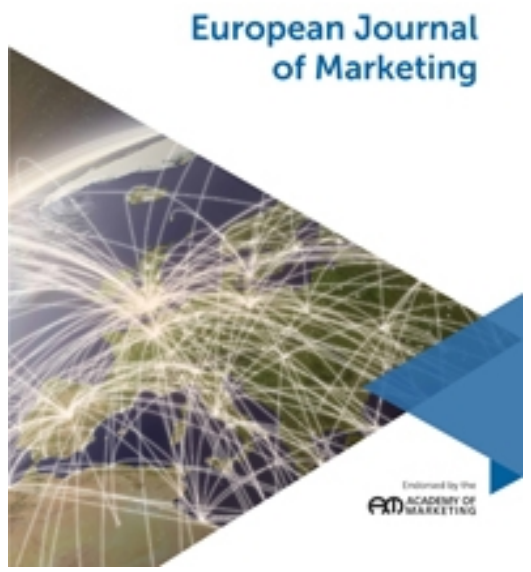

\section{Customer engagement with websites: a transactional retail perspective}

\begin{tabular}{|r|l|}
\hline Journal: & European Journal of Marketing \\
\hline Manuscript ID & EJM-10-2017-0649.R4 \\
\hline Manuscript Type: & Original Article \\
\hline Keywords: & $\begin{array}{l}\text { Customer engagement, Websites, Online retailing, Online consumer } \\
\text { behaviour, Fashion, Environmental psychology }\end{array}$ \\
\hline
\end{tabular}

\section{SCHOLARONE ${ }^{\text {m }}$ Manuscripts}


Customer engagement with websites: a transactional retail perspective

\begin{abstract}
Purpose - This paper focuses on customer engagement (CE) in the underexplored context of transactional retailing websites, providing insight into the drivers, manifestations and dimensionality of the construct. The website is viewed as a collection of environmental stimuli and focus is placed on identifying the website environmental cues that promote CE.
\end{abstract}

Design/methodology/approach - This focused study follows an exploratory research design. Twenty-two semi-structured interviews were conducted with one segment group: over 55 year-old female online shoppers in the most commonly purchased product category online, clothing. The Stimulus-Organism-Response (S-O-R) model forms the theoretical framework. Findings - The unique findings identify that product-related environmental cues drive $\mathrm{CE}$ on a website suggesting that $\mathrm{CE}$ occurs at the level of the product as opposed to the website.

Research limitations/implications - CE with websites exists beyond the customer-brand dyad with the website forming the third node in a triadic relationship between customer, brand (at level of the product) and website (at level of the product-related cues).

Practical implications - This study reveals the relationship between website environmental cues and the manifestation of $\mathrm{CE}$ providing insight to managers on how best to drive CE. Confirmation is provided that the website represents a vital touchpoint in the engagement journey of a retail customer.

Originality/value - Websites as a focal object for CE are markedly under-researched. This study empirically supports the relevance of considering CE in this context and reveals the influence online environments have on customer engagement.

Keywords - Customer engagement, Websites, Online retailing, Online consumer behaviour, Environmental psychology, Fashion

Paper type - Research paper

\title{
1.0 Introduction
}

Customer engagement (CE) has been attracting increasing attention in recent marketing literature and has been said to generate enhanced sales growth, superior competitive advantage and profitability, consumer value and to promote emotional connections/attachment, customer loyalty, trust, commitment and satisfaction (Hollebeek, 2011b; Kumar et al., 2010a; Kumar et al., 2010b; Bowden, 2009). The rationale being that engaged customers contribute to the firm's marketing function (Harmeling et al., 2017) play a role in generating product or brand referrals and/or recommendations, contribute to new product or service development, co-create experiences (Hollebeek, 2013; Brodie et al., 2011a; Kumar et al., 2010a) and make purchases (Maslowska et al., 2016). 
This has occurred against a backdrop of advances in online retailing. The online retail sector has grown exponentially with yearly sales almost trebling since 2007, reaching £59.7bn in 2017 (Mintel, 2018). In the UK, online retail now accounts for $18 \%$ of the total retail market with sales predicted to rise (ONS, 2018). In the face of the value of the online market, as well as the volume of competition that exists, many practitioners have begun to focus their efforts on engaging customers online in a bid to attract and keep them (Solomon, 2016).

To date, extant research lacks consideration of customer engagement with transactional retail websites. Jaakkola and Alexander (2014) note that CE research has considered the construct in an online context, however, the principal locus for this research has been online brand communities outwith the retailers' website, or the related domain of social media. This lack of focus on websites is significant as not only is CE considered to be context specific (Dessart, 2017; Brodie et al., 2011b; Hollebeek, 2011b), but websites have been referred to as "the cornerstone of internet activity for organisations" (Fill, 2013, p. 638) and is one of the few communication channels that can be completely controlled by a brand (Melewar et al., 2017). This article addresses the current gap in knowledge by focusing on CE in the context of transactional retail websites, specifically, fashion retailing websites. We purposefully selected this context as not only are clothing and fashion-related items the most commonly bought product category online making up nearly 33\% of all online sales (Mintel, 2018), but it is a highly competitive and volatile market sector where competitive advantage, which could be achieved through CE, is advantageous. Through their websites, retailers can sell products, provide information, facilitate two-way communication with customers, collect customer data and promote their goods and services (Doherty \& Ellis-Chadwick, 2009). With the website representing such a critical customer touchpoint for brands, this paper argues that promoting $\mathrm{CE}$ through this medium is a vitally important strategic objective for retailers.

In addition, despite the growing scholarly attention that $\mathrm{CE}$ has generated, understanding remains partial. Thus far, there is no consensus regarding a definition of CE, its dimensionality i.e. what constitutes customer engagement, or the established concepts to which it is related - including whether the act of purchase should be considered a manifestation of CE or not. The theoretical lens through which CE should be viewed is also uncertain. Among the various theories applied, some authors posit that the roots of CE lie in the domain of relationship marketing (e.g. Dessart et al., 2016; Hollebeek, 2011b) or the related theory of Service Dominant (S-D) logic (e.g. Bowden et al., 2017; Brodie et al., 2011a), whilst others adopt a consumer behaviour perspective (e.g. Islam et al., 2018; Gummerus et al., 2012). The theoretical perspective adopted when considering CE is 
important as a review of the existing body of literature reveals that it has a direct impact on its conceptualisation. For example, under both relationship marketing theory and S-D logic, CE is assumed to be highly interactive in nature (Hollebeek, 2011a) as customers are viewed as active contributors to brand interactions opposed to passive receivers (Vargo \& Lusch, 2008). From a consumer behaviour perspective, $\mathrm{CE}$ is considered at the level of the individual and is often conceptualised as a trait with the focus of scholars being on capturing the behaviour of customers by tracing the process from individuals' motivations to act, to the act itself and to the consequences of those actions (Islam \& Rahman, 2016).

In studies that do consider the transactional retail website as the focal object of engagement, Demangeot and Broderick (2016) adopt a dual relationship marketing and marketing communications perspective of $\mathrm{CE}$ citing that the stimuli on a website activates both communicational and relational responses in customers. Hyder and Bigné (2016) on the other hand, consider CE from a technological perspective, concentrating on identifying how customers engage online with websites as a digital medium. Whilst these studies provide insight, we believe that a transactional retail website warrants a consumer behaviour lens to be applied. A wide body of academic research (e.g. Hsieh et al., 2014; Wu et al., 2014) has established that a website's atmospheric or environmental cues - defined as any constituent of an online store within a shopper's perceptual field that stimulates the senses (Koo \& Ju, 2010), influences the behaviour of online shoppers. With website stimuli activating behavioural responses in customers and an established precedence to consider CE from a consumer behaviour theoretical perspective, the adoption of this lens facilitates a comprehensive understanding of the nature of $\mathrm{CE}$ in an online retail context. Specifically, by considering the environmental cues on a website, the nature of $\mathrm{CE}$ in this setting can be determined.

This study addresses three research areas: firstly, the question of how retail websites engage customers will be considered with a specific focus on identifying the environmental cues that stimulate CE. Secondly, the nature of CE with websites will be established by identifying the relationships between specific environmental cues and CE dimensions. Finally, insight will be provided into the role of the website in a customer-brand engagement process. Drawing from literature on customer engagement and consumer behaviour and using an interpretive research design, this article contributes to knowledge by identifying the role of the website in the customer-brand engagement dyad and establishing the nature of $\mathrm{CE}$ in this context from a hitherto unexplored theoretical perspective, namely consumer behaviour. 
The paper is organised as follows. The next section proceeds with a literature review that provides the theoretical background considering the construct of $\mathrm{CE}$ and the influence that website environmental cues can exert on consumer behaviour. This is followed by an outline and justification for the methodology and sampling frame adopted. The findings of the empirical research are then reported. Finally the key theoretical and managerial implications arising from the research are presented along with a future research agenda.

\subsection{Customer engagement}

\subsection{The definitions, dimensionality and focal objects of CE}

There is a lack of academic consensus regarding fundamental understanding of the definition of $\mathrm{CE}$ and its dimensions. Some researchers posit that the construct is uni-dimensional e.g. behavioural (e.g. Beckers et al., 2016; Dolan et al., 2016) whilst others take a multidimensional perspective commonly viewing CE to consist of traditional tripartite cognitive, affective and behavioural dimensions (e.g. Islam et al., 2018; Brodie et al., 2011a). Where agreement is growing is that CE is context dependent (Dessart et al., 2016; Brodie et al., 2011b). Some authors have attempted to provide general, empirically supported, definitions of CE that can be applied to differing contexts or focal objects. Based on their systematic literature review of CE research in marketing from 2005 to 2015, Islam and Rahman (2016) define CE as:

"The readiness of a customer to actively participate and interact with the focal object (e.g. brand/organisation/community/website/organisational activity), [which] varies in direction (positive/negative) and magnitude (high/low) depending upon the nature of a customer's interaction with various touchpoints (physical/virtual)” (p. 2019).

Interestingly, Islam and Rahman's (2016) definition of CE fails to outline its dimensionality, suggesting the nature of $\mathrm{CE}$ is indeed context specific and facilitating the generalizability of their definition. What can be established from this definition is that CE is a form of interaction with a brand, be that a specific brand touchpoint or activity that can be positively or negatively orientated. This is supported by the work of a number of scholars working in this field (e.g. Bowden et al., 2017; Hollebeek \& Chen, 2014). Furthermore, CE can exist at different levels of magnitude or intensity at different points in time - a view that is again shared (e.g. Brodie et al., 2011b; Hollebeek, 2011b). We are conscious of the fact that to our knowledge no studies to date have empirically established the dimensionality of $\mathrm{CE}$ in the context of transactional retail websites. It is our position that this should not be assumed and in this respect this paper shall take the lead from the work of Hollebeek et al. (2014) and Dessart et al. (2015) who specifically address the dimensionality of CE within the context of 
their empirical research. Regardless, this general definition provides a valid starting point for the consideration of $\mathrm{CE}$ with transactional retail websites.

With regards to the focal object of $\mathrm{CE}$, one important stream of research to have emerged is that of engagement with a brand itself (e.g. Hollebeek et al., 2014; Hollebeek \& Chen, 2014; Sprott et al., 2009). Considering engagement within the customer-brand dyad, customer brand engagement is defined as a customer's "cognitive, emotional and behavioural investment in specific brand interactions" (Hollebeek, 2011a, p. 555) where the brand can be conceived to include product (Patterson et al., 2006). This is relevant as the website represents a vital platform for retailers in facilitating and encouraging customer 'interactions' at both a brand and product level. To our knowledge the role that a website plays in stimulating engagement with a retailer's brand/product has not been considered. This study addresses this gap by identifying the environmental cues that stimulate $\mathrm{CE}$ and by determining the role of the website in the customer-brand CE dyad.

\subsection{Customer engagement: theoretical considerations}

The theoretical lens through which $\mathrm{CE}$ is viewed has also contributed to the wide-ranging and differing views regarding its dimensionality, definition and the constructs that it relates to. Table I presents the CE studies in which a clearly specified theoretical stance is adopted. The theoretical background assumed is outlined in the table, as is the focal locus of the study, the nature of the research (conceptual/empirical) and whether or not a specific theory (from the wider theoretical background) was applied. The studies are listed in chronological order and grouped by the theoretical perspective they have adopted. From Table I, it is clear that relationship marketing and the related 'Service Dominant' (S-D) logic are the principal theoretical lenses through which $\mathrm{CE}$ has been viewed.

The concepts of interactivity and co-creation are central to CE from an S-D logic perspective (e.g. Hollebeek et al., 2016; Breidbach et al., 2014) and a number of customer actions have been identified as reflecting these concepts including: word-of-mouth activity, customer-tocustomer interactions and/or blogging (Brodie et al., 2011a; Brodie et al., 2011b; van Doorn et al., 2010). However, it is our position that these behaviours (and arguably the concept of co-creation) are specific to the context of social media or online brand communities - as has been the principal focus of $\mathrm{CE}$ research to date. On most transactional retailing websites today, there is little to no opportunity for customer-to-customer interaction as brand-operated online 'chatrooms' have been removed by brands in favour of major social media platforms. Despite this, S-D logic has been broadly utilised as the theoretical prism through which to explore CE. 
[INSERT TABLE I NEAR HERE]

Table I illustrates that a body of work has continued to consider CE from a consumer behaviour theoretical perspective viewing behavioural expressions of customers as manifestations of CE. These behaviours have been conceptualised to include a range of actions such as contributing to word-of-mouth communications, providing recommendations or referrals, blogging and engaging in interactions with brands (Dolan et al., 2016; Kumar et al., 2010a). It is important to note that whilst these behaviours are the same as those identified from a relationship marketing/S-D logic perspective, it is the identification of the action or behaviour itself that is significant in the consumer behaviour perspective not the opportunity for co-creation to take place. Kumar et al. (2010a) argue that a behavioural view would be incomplete without the inclusion of customer purchase behaviour as they submit that purchase is a key way in which customers can interact or 'engage' with a firm. However, Harmeling et al. (2017) observe that the general consensus among scholars is that CE is a customer's behavioural response to a firm outwith the core economic transaction.

This paper adopts a consumer behaviour perspective to explore CE with transactional retail websites. We posit that this theoretical lens will support the identification of the website environmental cues that stimulate $\mathrm{CE}$ and facilitate the nature of their influence to be determined. Academic research has established that website environmental cues impact customers' behaviour confirming the applicability of adopting a consumer behaviour perspective in this study. This research shall be considered in the next section.

\subsection{Consumer behaviour activated by retail websites}

The discipline of consumer behaviour is concerned with how individuals (customers) spend their resources - which go beyond financial resources to include time and effort - on consumption-related items and processes (Solomon et al., 2016). Technological advances, including the internet, have prompted a wealth of academic research into 'online consumer behaviour' with a key stream of research considering the impact that website environmental cues have. Demangeot and Broderick (2007) posit that research participants must be viewed as consumers. This distinction is significant as consumption activity is moderated by specific consumer motivations and goals that often supersede the acquisition of products such as entertainment (Demangeot \& Broderick, 2007). In viewing retail website users as shoppers, consumer perceptions of the website as a shopping environment, rather than its technical properties as a computer-mediated interface, emerge. Thus, we view the website as a key strategic customer touchpoint through which retailers can sell goods and engage customers 
and posit that to establish the nature of $\mathrm{CE}$ with websites, the website environmental cues that elicit $\mathrm{CE}$, and have hitherto been ignored, must be explored.

Much of the extant literature pertaining to online consumer behaviour is focused on the influence of website environmental cues at an individual level. Few attempts have been made to consider the website as a holistic environment. For example, Kim and Lennon's (2008) examination of online product presentation formats (visual/picture and verbal/text) and their influence on purchase intention identified the more important role of verbal product information over visual presentation. More recently Kim and Lennon (2010) found that a high level of product detail reduced customers' perception of risk and increased their satisfaction. Hou et al. (2017) studied both quantitative and qualitative features of online reviews and noted that both were important predictors for creating online sales. Whilst Wu et al. (2014) determined that website layout stimulates emotional arousal and positive attitude toward a website increasing purchase intention. Whilst these studies have shown that individual features have a direct influence on consumer behaviour, they fail to capture the influence of a website in its entirety. This study adopts the view that a retail website is the totality of its individual environmental cues and as such we did not identify a particular cue for investigation but instead established those that impact $\mathrm{CE}$, as well as the nature of this influence, through primary research.

Scholarly enquiry has shown that a customer's online shopping motivation affects customer behaviour. A body of research conducted across all product categories posits that the orientation of a customer's motivation - specifically whether an individual is driven by hedonic or utilitarian considerations, influences individual customer behaviour and attitudes towards online shopping (e.g. Bridges \& Florsheim, 2008; Childers et al., 2001). According to Babin et al. (1994) hedonic motivations reflect a customer's desire for entertainment and emotional connection and can be indicated by increased levels of arousal, involvement, escapism and fantasy. As such they typically seek a pleasurable and entertaining experience from a website (Wolfinbarger \& Gilly, 2001). Utilitarian motivations are typically goalorientated and functional and involve a cognitive and rational response (Babin et al., 1994). In contrast, utilitarian online shoppers are concerned with product-related features such as quality, price and usability and have been found to be influenced by the task-related features of a website (Wolfinbarger \& Gilly, 2001).

\subsection{Theoretical framework for the study (S-O-R)}

The Stimulus-Organism-Response (S-O-R) model (Mehrabian \& Russell, 1974) has formed the basis for many studies conceptualising behavioural intention. The S-O-R model posits that 
the retail environment contains stimuli (S) that cause reactions or internal states in customers or 'organisms' $(\mathrm{O})$, that generate a response (R) that is often behavioural. Whilst environmental psychology research has long established that retailers can manipulate the atmosphere of the shopping environment to affect shopper reactions, it was Eroglu et al. (2003) who validated the relevancy of the framework to online shopping.

Despite the lack of tactile, olfactory and often auditory cues online, Eroglu et al. (2003) identified the existence of online 'atmospherics' that led to affective and cognitive internal states and resulted in a behavioural customer response. These were categorised into high and low task-relevant cues (Eroglu et al., 2003). High task-relevant cues refer to all the verbal and visual content on a website that facilitates the task of shopping and therefore are central to the achievement of utilitarian customer motivations. This includes product descriptions, product images, price, terms of sale, delivery and returns policies, and website navigation aids. Low task-relevant cues refer to the components of the website inconsequential to the completion of the shopping task such as the colours, fonts, borders, patterns, animations, entertainment and images other than product images. Ultimately, these are cues that support the hedonic motivations of shoppers (Eroglu et al., 2003). Advances in technology since Eroglu et al.'s (2003) seminal work, have resulted in new website features that can be added to those lists. Product demonstration videos, customer reviews and live chat facilities can all be categorised as high task-relevant cues. New low task-relevant cues include links to the retailer's pages on social media platforms (termed social media 'plug-ins') and editorial content such as online magazines and blogs.

The S-O-R model has been utilised as a framework through which to operationalize the construct of CE (Islam \& Rahman, 2017; Demangeot \& Broderick, 2016; Claffey \& Brady, 2014; Mollen \& Wilson, 2010). Significantly, both Demangeot and Broderick (2016) and Mollen and Wilson (2010) consider CE with websites and identify cognitive and affective organismic states and behavioural responses as typifying an engaged customer condition. However, neither of these studies explicitly consider nor identify the environmental stimuli or website cues that promote $\mathrm{CE}$, nor do they identify the precise manifestations of these cognitive, affective or behavioural CE responses. By applying the S-O-R model at the level of each identified cue $(\mathrm{S})$, the customer's internal state $(\mathrm{O})$ leading to customer engagement $(\mathrm{R})$ is determined. We posit that the individual application of the S-O-R framework facilitates a level of consistency in the consideration of each cue - which is important as the cues differ substantially in nature (i.e. verbal/visual etc.). Empirical confirmation of the dimensionality of CE with websites is also provided. 


\subsection{Methodology}

In light of the lack of extant research on CE with websites and based on the premise that CE is context specific (Dessart, 2017; Brodie et al., 2011b; Hollebeek, 2011b), this study took an overall exploratory approach within an interpretative research design. In-depth semistructured interviews were used to establish the website cues that drive $\mathrm{CE}$ as well as the nature of this engagement. Purposive sampling was conducted with participants selected on the basis of their age, gender and prior experience of shopping for fashion online: specifically, over 55 year-old women who have browsed and bought fashion and fashion-related items online. The propensity among researchers from all disciplines to use student samples as they are accessible, convenient and cost effective has attracted widespread criticism due in large part to the limited generalizability such samples afford (Bello et al., 2009). In fact, authors considering online customer shopping behaviour have identified the use of student samples as a key limitation within the extant body of research, citing the fact that students are most likely to be more computer literate than other age groups, more comfortable shopping online (Doherty \& Ellis-Chadwick, 2010; Demangeot \& Broderick, 2007) and therefore not representative of the population as a whole. Supporting this, Chiu et al. (2014) found that older customers possess significantly more barriers to shopping online than their younger counterparts; thus suggesting that if they experience $\mathrm{CE}$ with a website then younger customers will too. In response to this, our study identified over 55 year-old women as the target sample. According to the Office for National Statistics (ONS) the over-55s is the fastest growing demographic group in the UK leading market analysts Mintel to identify this customer group as one that represents a significant opportunity for fashion retailers (Mintel, 2016). Women were selected as they are significantly more likely than men to shop for fashion online (Mintel, 2017). Having prior experience of browsing and buying fashion online was an important criterion as we believe that for participants to contribute effectively, they need to have had experience of shopping for fashion online so that they might then offer insight into whether this has led to a state of CE.

To the best of our knowledge, no qualitative research has been conducted on CE in the context of retail websites and so this study will address this gap. This qualitative approach answers calls from Demangeot and Broderick (2016) who identified a need, through their own study considering website $\mathrm{CE}$, for interpretative research considering how website attributes stimulate $\mathrm{CE}$.

Twenty-two semi-structured interviews lasting on average 46 minutes were conducted with over 55 year-old women (specific age range being 55-78) who are members of a charity fundraising social group for women approaching and in retirement, based in a Scottish city. 
Belonging to the same social group could be perceived as a niche sample frame, and potentially viewed as a limitation of this study, thus it is important to highlight that the group only share a common aim - this being to raise money for charity, in all other respects i.e. level of education, income, careers/previous careers etc., the group are fragmented.

Participants were instructed to recall a fashion retailing website with which they felt they had experienced $\mathrm{CE}$ when browsing or buying and were asked to describe their thoughts, feelings and behaviours when in this engaged state. Initially, the research questions were open-ended with participants encouraged to offer their own definition or particular expressions of $\mathrm{CE}$ with a retail website. Further into the interview, participants were provided with Islam and Rahman's (2016) definition of CE adopted by this study and terms drawn from literature related to the cognitive, affective and behavioural aspects of $\mathrm{CE}$, thus allowing their experiences to be probed further and in line with previous academic enquiry. In particular, respondents were asked to identify specific environmental cues that promoted their engagement with the website (e.g. product images). The data was coded and recoded four times and themes were identified in line with Bryman's (2016) procedure for conducting thematic analysis which involved elaborating the codes into themes where possible; refining the themes and testing the propositions; examining links and connections between the themes; and writing up findings. Data saturation (Glaser \& Strauss, 1967) was sought and achieved after 22 semi-structured interviews.

\subsection{Findings}

This section presents the findings of this study. Individual website environmental cues that incite $\mathrm{CE}$ are identified and the nature of this relationship, in terms of the dimensions of $\mathrm{CE}$ that are stimulated and their manifestations, are determined. The influence that a customer's internal motivation exerts on the nature of $\mathrm{CE}$ they experience is also captured. Confirmation is provided that $\mathrm{CE}$ with transactional retail websites comprises of cognitive, affective and behavioural dimensions. Furthermore, the findings allow conclusions to be drawn on the role that the website plays in the customer-brand engagement dyad.

\subsection{Drivers of customer engagement with retail websites}

Our analysis identifies that both internal and external influences drive CE. The orientation of a customer's motivation, specifically, whether a customer is driven to shop online to fulfil utilitarian or hedonic needs, is the internal influence that drives CE, whilst individual environmental cues of the website act as external influences.

\subsubsection{Internal influences}


What is significant from Customer 4's response is that instead of visiting particular websites based on prior knowledge of the retailer or brand, interaction with a retailing website is driven at the level of the product. It is, in fact, the search for a particular product that leads the customer to interact with a retailer's website in the first place. This behaviour was commonplace among respondents:

"I will go on lots of different websites to look for say, a pair of trousers and I will look at just that. I won't look at anything else". Customer 1.

There is a precedent in scholarly enquiry considering brand engagement to consider product as a brand (e.g. Patterson et al., 2006). However, the findings of this study suggest that in terms of $\mathrm{CE}$ with transactional retail websites, there is a clear distinction between the brand and product with $\mathrm{CE}$ occurring at the level of the product. In their study considering websites as a vehicle for communicating brand value, Mollen and Wilson (2010) define brand engagement as "the cognitive and affective commitment to an active relationship with the brand as personified by the website" (p. 5). The implications drawn from this study with regards to retail websites are that online retailers would need to foster an active relationship between customers and their products to achieve and maintain brand engagement:

"If I have seen something I like on Google or say a department store's website, I often then will go and look at that brand's own website to see what else they have like it. If I like what else they have then I'll go back to that [brand's] website in future". Customer 7.

These results extend the findings of Dwivedi (2015) who proposes that product category involvement - i.e. the extent to which the consumer perceives a product category to meet their particular needs, interest and values - has a positive impact on the manifestation of brand engagement. However, we posit that it is not involvement with the product category in general but with individual products that leads to positive $\mathrm{CE}$ with a brand, with a process 
relationship existing between the two. This was equally as evident in the accounts of participants who reported being engaged with a particular retail brand:

"I often look at Next's website because I have bought a lot from them and I know what size fits me and I like their style". Customer 9.

Here CE with the retailer is driven and maintained at the level of the brand's products with an interplay evident between customer engagement with the product and with the brand - a phenomenon that Bowden et al. (2017) refer to as a 'spillover effect'. Thus, it is prior positive engagement with the product that 'spills over' and drives continued engagement with the brand.

Whilst most respondents were motivated to shop online for utilitarian reasons some did express hedonic motivations such as the pursuit of enjoyment or leisure.

"I shop for fashion online every Friday night with a glass of wine. I don't always buy but I do look". Customer 9.

Table II outlines the website environmental cues that were identified by participants as stimulating their engagement.

\section{[INSERT TABLE II NEAR HERE]}

\subsubsection{External influences}

Website environmental cues, specifically high task-relevant cues, which capture all the verbal and verbal content on a website that facilitates the task of shopping (Eroglu et al., 2003), are the external driver of CE. Product images, product information regarding washing instructions and fabric composition, i.e. the percentage mix of fibres the fabric contains, product demonstration videos, ease of navigation around the website and customer reviews are all cues on a website that customers engaged with regardless of whether they possessed utilitarian or hedonic motivations (see Table II). Significantly, all customers demonstrated a lack of interest in any design or entertainment features of a retail website. This finding contradicts the seminal work of Eroglu et al. (2003) who posit that low task-relevant cues e.g. colour, font, music - or the components of a website that are surplus to the achievement of the shopping task - support the goals of hedonic shoppers. In fact, the findings of this study indicate that low task-relevant cues play no role in driving CE. This is reflected by Customers 
9 and 17 who, despite predominantly exhibiting hedonic motivations for shopping, were not interested in any form of entertainment offered by a retail website:

"For me it is product driven, I'm not looking for an experience from the website at all". Customer 9.

"The websites I like are plain and simple. I can't stand things that pop-up, pop-down, move about, play music". Customer 17.

Demangeot and Broderick (2007) identified that online shopping environments were perceived in a more cognitive manner than offline environments and as such, it may be that hedonic considerations such as the design of a website, wield little influence. It may also be the case that in the intervening years since Eroglu et al.'s (2003) seminal work, expectations of websites have changed and customers now simply assume a good level of aesthetic quality. An observation that was made by a number of respondents was that most websites today look the same, opting for white backgrounds and clear, easy to read fonts, so it may be that Eroglu et al.'s (2003) low task-relevant cues are no longer relevant as they have become uniform.

\subsection{The impact of website environmental cues on the manifestation of $\mathrm{CE}$}

Analysis of the interviews confirms that $\mathrm{CE}$ is composed of three dimensions: cognitive, affective and behavioural. This not only provides support for the conceptualisation of CE as a construct consisting of these tripartite dimensions (e.g. Bowden et al., 2017), but importantly deepens our understanding of them in this context as the rich online shopper data reveals that individual website environmental cues (as identified in Table II) activate particular dimensions of $\mathrm{CE}$. This relationship is somewhat modified by the internal motivation (utilitarian/hedonic) of the customer and is captured in Table III.

The cognitive dimension captures $\mathrm{CE}$ as an active state of mind experienced in relation to the focal object of engagement (Islam \& Rahman, 2016; Vivek et al., 2012) and is manifested in the form of attention (Bowden et al., 2017; Dessart et al., 2015) on the part of the customer defined as the dedication of cognitive activity on a particular stimulus (Huang, 2003). The affective dimension of $\mathrm{CE}$ with websites relates to the emotions a customer will experience in relation to their focal object (Vivek et al., 2012) and is captured by a state of positive affect (Bowden et al., 2017; Hyder \& Bigné, 2016). The behavioural CE dimension reflects the resources - in terms of energy, effort and/or time - that a customer expends on interactions with the focal object (Hollebeek, 2011a) and is expressed by activation (Bowden et al., 2017; Hollebeek, 2011a). 


\section{[INSERT TABLE III NEAR HERE]}

Website environmental cues were found to stimulate cognitive and/or affective dimensions of CE. Participants expressed their cognitive CE through statements that revealed their concentrated thought (Huang, 2003) when interacting with a website cue:

[Cue: Fabric composition/product specification] "I don't like fitted clothes I like oversized clothes so I'll look at how it sits on the model and I'll go down to the product description and see if it uses words like 'long', 'floating', 'oversized' and I'll also try and identify the fabric because I don't like tight fabric with Lycra in them". Customer 13.

Affective CE was captured in interviewees' expressions of positive emotion (e.g. like, enjoyment, excitement) induced by a website cue:

[Cue: Product images] "There are some websites that stage their clothes really well. Like they'll have a model wearing summer holiday clothes next to a pool. It helps me get in the mood for holiday". Customer 15.

The internal utilitarian/hedonic motivation of the customer was found to have a modifying effect on these relationships albeit a limited one as the engagement dimensions stimulated by each website cue were the same for all customers. What was impacted was the order in which the dimensions were stimulated when both cognitive and affective facets were experienced (indicated by the arrows in Table III). For example, hedonically motivated customers reported an initial affective reaction (such as liking or excitement) on seeing product images and product demonstration videos that engaged them, which was followed by a cognitive response (such as the move to find out more information):

[Cue: Product demonstration video] "With clothes it is really good to see how they will fit. You can almost learn more about how the fabric will look from them than reading what it is made of as not all polyester, for instance, is the same". Customer 9.

Customers motivated by utilitarian means also experienced both cognitive and affective reactions to product image and video cues but in contrast the cognitive response was stimulated first: 
"I would say that to be engaged with a website it is first of all functional; like 'I need something new for work', but once you are on that website I think it becomes an emotional experience as you start to feel as there'll be things you like and things that you don't like". Customer 2.

Despite the fact that Customer 2 does not explicitly refer to the website environmental cues that she interacted with, CE existing at the level of the product which is stimulated by the product-related cues of a website is strongly evidenced here. Further support for this is provided from Customer 14:

"If I am looking for something that is it; I will keep searching until I find it, all night if I have to". Customer 14.

The sentiment expressed here points to the existence of a level of duality in terms of product engagement. Here, the respondent is displaying high levels of product engagement (with the desired product) whilst encountering, perhaps vast quantities of, non-engaging products. Hollebeek et al. (2014) observe that customers exhibit "a substantially lower willingness to exert cognitive, emotional or behavioural activity" (p. 152) with non-engaging brands. These results support this in the context of non-engaging products as respondents recounted experiences of "scrolling through" (Customer 3), "scanning" (Customer 14) or "glancing over" (Customer 8) non-engaging products when shopping online. Interestingly, whilst these customers were exhibiting limited cognitive, affective or behavioural responses with much of the products they encountered, they were in fact simultaneously experiencing a heightened state of engagement with their desired product and the resultant search.

Navigation, specifically ease of navigation, was the only environmental cue identified by participants that can be classified as relating to the website (opposed to the product). The importance of ease of navigation in inducing positive customer attitudes to online shopping among both utilitarian and hedonic customers has been documented (Childers et al., 2001) but the role that it assumes in stimulating, or perhaps even more vitally maintaining, $\mathrm{CE}$ is revealed here:

“When the website doesn't take you to where it should - argh!". Customer 12.

Difficulty in navigating a website was found to induce intensely negative cognitive and/or affective responses among the research participants with sentiments of irritation, annoyance, 
frustration and impatience all expressed and typically leading to disengagement with the website.

\subsection{Behavioural CE responses}

A number of behavioural responses of $\mathrm{CE}$ with retail websites were identified outwith the core economic transaction (Harmeling et al., 2017). These include: leaving the website with the intention to return at a later date, leaving the website to visit the retailer's physical stores (if available), engaging with the retailer through other communication channels and engaging with loyalty schemes. Disengagement or a less permanent but related state of 'dormancy' was identified as being part of the CE process.

A number of participants highlighted that they would actively choose to leave the website in favour of visiting that retailer's physical store:

"I like to touch and feel and see the fabrics and clothes - and try them on. So I'll do a lot of research online and then I'll physically go and look at them in stores". Customer 1.

Whilst this particular behaviour could be attributed to the nature of the product category under discussion, as research has established that apparel consumers will often base their purchasing decisions on sensory interaction with the products (Underhill, 1999), this response suggests that CE with a website is part of a wider nomological network or 'ecosystem' (Maslowska et al., 2016; Breidbach et al., 2014). Here the customer remains in a state of CE after they have left the website as they choose to interact again with the product, and arguably with the brand (Hollebeek et al., 2014), through another touchpoint. This is further supported by the other behavioural responses identified such as interacting with other communication channels. For example, several participants reported signing up to direct marketing mailing lists and seeking out discounts or catalogues from that retailer. Interestingly, very few participants considered social media as a further communication channel through which to interact with retailers, and even less actually used them:

"I use Facebook, Pinterest, What's App; but not to look at shops or clothes. Absolutely not. It is for keeping in touch with family and friends". Customer 18.

The age of the interviewees in this study may factor in this result as worldwide research has established that younger consumers - specifically those aged 18-24 - are more likely to interact with brands on social media than other age groups (Statista, 2014). Interestingly, a number of participants did state that advertisements on social media would often prompt them 
to visit a retailer's website indicating that interaction, and potentially $\mathrm{CE}$, would flow from social media platforms to the website within an engagement ecosystem:

"I often see something on Facebook and I like the look of it so I'll go to the website".

\section{Customer 3}

The majority of participants indicated that they viewed participation in loyalty schemes as a manifestation of CE:

"For me to be engaged with a retailer it would be where I have been on their website and signed up for their emails or their [loyalty] cards. I've signed up then, I'm engaged, I'm in". Customer 3.

The relationship between $\mathrm{CE}$ and customer loyalty has been empirically supported in a number of studies (e.g. Fehrer et al., 2018; Hollebeek, 2011a), which is not surprising in light of the relationship marketing lens commonly adopted in the consideration of CE. Interestingly, this study also supports the link from a consumer behaviour perspective, as here customers perceive the act of enrolling onto brand loyalty schemes as a manifestation of CE.

These unique findings indicate that the website, physical stores, direct marketing, social media and loyalty schemes all act as 'engagement platforms' (Breidbach et al., 2014) for retailers within a broader nomological engagement network.

The final behavioural responses identified were dormancy or disengagement. In their article considering CE in virtual brand communities, Brodie et al. (2011b) distinguish between the states of dormancy and disengagement based on permanency defining dormancy as, "a temporary state of inactive, passive engagement by individual consumers who have been more actively engaged" (p. 110). Disengagement, on the other hand, is indicative of a longer lasting or more permanent cessation of engagement (Brodie et al., 2011b). In the context of transactional retail websites, analysis of the data reveals that dormancy is reflective of customers who leave a website accompanied by a neutral cognitive and affective internal state whereby the states of attention and positive affect are not present but neither are any negatively-valenced states:

"If I don't see anything I'll leave there and go elsewhere... usually back to the search engine search and look at the other items that have come up". Customer 16. 
In this aspect it differs from customers leaving the website with the active intention to return, as positive cognitive and emotional states of $\mathrm{CE}$ were found to be present in these cases. In contrast, disengagement is often accompanied by negative thoughts and emotions on the part of the customer:

"To be disengaged with a website would be to be irritated or frustrated by it. I would just come off and I wouldn't go back. Why bother?" Customer 18.

The negative cognitive and affective responses expressed here mirror the findings of Bowden et al. (2015) who established a link between the non-fulfilment of customers' hedonic or utilitarian motivations and the construct of disengagement. From the analysis of the results in this study, it is evident that to reach a state of dormancy or disengagement, a customer would bypass positive cognitive and affective CE states, experiencing either neutral or negativelyvalenced states. Essentially, this means that should a customer's internal state not be expressed positively, they would move straight to a state of dormancy (accompanied by a neutral response) or disengagement (accompanied by a negative response) thereby leaving the website. This process could take just a matter of minutes to occur.

It is important to note that when asked to identify the consequences of their engagement with a retail website respondents repeatedly discussed the act of purchase:

“I would say I've been engaged with the White Stuff website - I've bought a lot from them". Customer 14.

"[To be engaged] is to buy something". Customer 21.

"When I actually part with my money". Customer 7.

In line with the general scholarly consensus that CE exists "beyond financial patronage" (Harmeling et al., 2017, p. 316) this study has focused on individuals' behavioural responses outwith the core economic transaction. However, the results here suggest that this is not necessarily reflective of the thoughts, feeling and opinions of customers.

\subsection{Discussion}

\subsection{Theoretical implications}

This study examines customer engagement in the underexplored context of transactional retail websites. Responding to calls for further research into $\mathrm{CE}$ with individual customer touchpoints (Fehrer et al., 2018) and specifically for interpretivist research into CE with websites (Demangeot \& Broderick, 2016), this study employed a qualitative methodology 
consisting of 22 in-depth semi-structured interviews. The findings identify the website environmental cues that stimulate $\mathrm{CE}$ and provide insight into these relationships. Furthermore they indicate that the website represents an important $\mathrm{CE}$ touchpoint within a wider CE ecosystem.

The findings reveal that $\mathrm{CE}$ with transactional retail websites can be conceptualised as a phenomenon beyond dyadic customer-brand interactions, supporting the work of Fehrer et al. (2018). However in contrast, this study finds that it is not other customers who form the third node of a triadic relationship structure in this context but the website itself. There is a body of $\mathrm{CE}$ research that draws on the principles of social psychology to consider the influence of customer-to-customer interaction on the engagement process (e.g. Dessart et al., 2015; Brodie et al., 2011b). The unique findings of this study identify the effect that website environmental cues have on the manifestation of $\mathrm{CE}$ and confirm the validity of considering $\mathrm{CE}$ through the lens of environmental psychology. Previous CE studies that have considered the website as the focal object of engagement (e.g. Demangeot \& Broderick, 2016; Claffey \& Brady, 2014; Mollen \& Wilson, 2010) have not considered the website at the level of its individual environmental cues, which is significant as this study has revealed and empirically supported that this is where CE with a retail website occurs. Specifically, within the customer-brandwebsite triadic relationship, $\mathrm{CE}$ with a retail brand exists at the level of the product and is driven by the website at the level of high task-relevant cues (Eroglu et al., 2003).

This finding is significant, as recent scholarly enquiry has begun to move from considering CE with single focal objects, such as an online brand community (Dolan et al., 2016) to multiple engagement objects such as the online brand community and the brand (e.g. Bowden et al., 2017; Gummerus et al., 2012) in order to capture a holistic understanding of the phenomenon. This has been facilitated by the vast body of work that considers CE in the context of social media/online brand communities whereby it has been empirically established that the brand community as well as the brand itself, represent focal objects for CE. In contrast the limited consideration of websites in CE research has meant that until now the focal engagement objects relevant to a website i.e. product/high task-relevant website environmental cues, have not been revealed.

Considering product as a focal object of CE presents considerable theoretical implications for the development of understanding of the construct, as much of the extant literature considers $\mathrm{CE}$ within the broader context of firms moving from a product-centric to a customer-centric approach (e.g. Sashi, 2012; Vivek et al., 2012). It is this that has largely driven the theoretical lenses through which $\mathrm{CE}$ is viewed, with the principal perspectives adopted being relationship 
marketing and S-D logic - where service provision rather than just goods is central (Vargo \& Lusch, 2004). The results of this study suggest that this product-to-customer paradigmatic shift may not best foster CE; that said, it is important to highlight that the results do not indicate that the marketing function requires a re-orientation back solely around product. Instead, we posit that this study has highlighted the importance of product, particularly in light of the positive 'spillover effect' (Bowden et al., 2017) of CE from product to brand, and suggest this represents a potentially important locus for future CE research.

Analysis lends support for the conceptualisation of customer engagement existing as part as of a wider nomological network or 'ecosystem' (Maslowska et al., 2016; Breidbach et al., 2014). The positive behavioural CE responses whereby customers leave the website to visit a physical store or engage with the retailer via alternative touchpoints such as other communication channels or loyalty schemes, indicates that $\mathrm{CE}$ with the website is one component in a dynamic, non-linear process (Fehrer et al., 2018; Brodie et al., 2011a). The fact that engaged customers were found to leave the website with the intention to return at a later date further confirms the conceptualisation of the process of $\mathrm{CE}$ to be an iterative one (Brodie et al., 2011b). However, whilst this study provides support for previous understanding of the construct it also provides unique insight into a previously underexplored touchpoint in a customer's engagement journey with a retail brand - the website. The website represents a vital component of the current (and conceivably, future) 'omni-channel' shopping environment where customers can engage with retail brands through a multitude of channels: website, physical retail stores, social media, apps, direct marketing etc. (Verhoef et al., 2015). Fehrer et al. (2018) posit that "practitioners should pay attention to specific 'engagement' antecedents and consequences when implementing engagement ecosystems" (p. 605) highlighting the importance of understanding the nature of CE with each customer touchpoint. A body of research has emerged identifying the nature of $\mathrm{CE}$ along with the drivers and consequences in various online contexts - most commonly social media or online brand communities (Maslowska et al., 2016), but this extant research has failed to consider the transactional retail website in any depth. Acknowledging that $\mathrm{CE}$ is context specific (Dessart et al., 2016), this study provides valid and important insight into CE with this retail setting that could be drawn upon alongside findings from CE studies with other focal objects e.g. social media, as part of a holistic approach to understanding the engagement ecosystem in an omni-channel retail business structure.

The results of this study have allowed us to draw a clear distinction between a dormant state of CE and disengagement (Brodie et al., 2011b) revealing the valence of the cognitive and affective state accompanying each. Whilst both involve a behavioural response i.e. leaving 
the website, dormancy is accompanied by a neutral cognitive and affective response. Disengagement is typified by exiting with a negative internal state such as annoyance or frustration. Following our support for the existence of an engagement ecosystem we posit that to fully capture an online retail customer's engagement journey, dormancy and disengagement must be considered alongside the positive behavioural expressions of $\mathrm{CE}$ with a website.

\subsection{Managerial implications}

Analysis has shown that in the context of transactional retail websites CE occurs at the level of the product rather than the brand with $\mathrm{CE}$ with the former potentially leading to the latter. Whilst the positive relationship between product involvement and brand engagement had been previously identified (Dwivedi, 2015) the process nature of this relationship whereby brand engagement occurs as a direct consequence of product engagement had not. The implications of this are significant for managers as they suggest that product, and productrelated website cues, should be viewed as a gateway to brand engagement and as such, represent an opportunity for retail brands to communicate their personality and/or values. Brand managers today already use their company website to communicate this information (Melewar et al., 2017) but often this occurs away from product listings/cues. The results here suggest that incorporating brand messages where possible into the high task-relevant cues found to stimulate $\mathrm{CE}$, could better foster brand engagement. For example visual and verbal cues should capture the brand's values, image and ethos. Furthermore, when incorporating brand messages managers should draw upon the findings regarding the $\mathrm{CE}$ dimension triggered by each cue.

The results reveal that the website represents an important touchpoint within a larger engagement ecosystem and that online retail customers will move between touchpoints (e.g. website, social media, physical stores, loyalty schemes) throughout their engagement 'journey' with a brand. We mirror the recommendations of Breidbach et al. (2014) that brand managers should configure their operations to create the ideal engagement ecosystem to foster CE. Nevertheless, we would extend this. The unique findings of this study have identified the triadic nature of $\mathrm{CE}$ with a transactional retail website with a relationship existing between the customer, the brand (at the level of the product) and the website (at the level of environmental cues). Studies conducted in other contexts have similarly revealed multiple focal engagement objects - but these differ. For example in their consideration of online brand communities, Bowden et al. (2017) identify CE existing between the customer, the brand and other customers. Therefore we posit that the engagement ecosystem should be viewed as a macro level construct with each customer touchpoint representing a micro 
element requiring its own individual in-depth consideration and configuration. To this end we suggest that managers use our research in conjunction with that conducted in other contexts e.g. social media, to effectively foster $\mathrm{CE}$ with each touchpoint in a brand's engagement ecosystem.

\subsection{Limitations and further research}

This research represents a first attempt to conceptualise CE with retail websites from a consumer behaviour perspective, drawing upon environmental psychology theory to identify the website environmental cues that drive CE. However, we acknowledge that limitations exist and recommend some areas of further research. The relatively small sample size could be viewed as a limitation of this study and whilst the point of data saturation (Glaser \& Strauss, 1967) was reached, future study could work towards validating these results through further empirical research.

Future research could replicate this study in other product categories or across all product categories. Equally, the consumer demographic group considered could be widened. Over 55 year-old women were selected for this study due to their propensity to shop for fashion online and to avoid the criticisms levelled at studies that employ student samples to consider computer-related interfaces due to the high level of their computer literacy. Whilst we believe that this has provided a good foundation for the understanding of $\mathrm{CE}$ with retail websites, a wider demographic sampling frame may offer new insights into the phenomenon.

The findings show that $\mathrm{CE}$ with a transactional retail website occurs within a wider ecosystem of engagement consisting of various off and online customer touchpoints of which the website is one. The findings suggest that physical stores, direct marketing, social media and loyalty schemes represent other key touchpoints for retail customers, and whilst social media has been a commonly considered context within CE enquiry, we posit that the others warrant further dedicated consideration to identify the process through which they foster CE. With the development of technology making omni-channel retailing inevitable (Brynjolfsson et al., 2013) this provides a rich backdrop to future enquiry.

Within extant CE literature there is a lack of agreement regarding whether the act of purchase is a manifestation of CE. Some academics view purchase as a key method through which customers can engage with a firm (Kumar et al., 2010a) others posit that CE takes place outwith the core economic transaction (Harmeling et al., 2017; van Doorn et al., 2010). Yet the act of purchase forms a vital stage in the shopping process (Kim \& Eastin, 2011; Chen \& Chang, 2003) and to omit this from consideration through the lens of customer engagement 
may mean that engagement with the full shopping journey is not being captured. Moreover, the respondents of this study repeatedly referred to purchase as a manifestation of their engagement with a retailer and their website. Therefore we posit that further consideration of the relationship between purchase and CE is important to the development of understanding of $\mathrm{CE}$ in a retail context. Nevertheless, from this vantage point, this study has contributed important insight not only into the underexplored area of CE with websites, but into online consumer behaviour in general. 


\section{References}

Babin, B., Darden, W. and Griffin, M. (1994), "Work and/or fun: Measuring hedonic and utilitarian shopping", Journal of Consumer Research, Vol. 20 No. 4, pp. 644.

Beckers, S.F.M., Van Doorn, J. and Verhoef, P.C. (2016), "Economic outcomes of customer engagement: Emerging findings, comtemporary theoretical perspectives, and future challenges", in Brodie, R.J., Hollebeek, L.D. and Conduit, J. (Ed.), Customer Engagement: Contemporary issues and challenges, Routledge, Abington, Oxon, pp. 21-52.

Bello, D., et al. (2009), "From the Editors: Student samples in international business research", Journal of International Business Studies, Vol. 40 No. 3, pp. 361-364.

Bowden, J.L.H., Gabbott, M. and Naumann, K. (2015), "Service relationships and the customer disengagement - engagement conundrum", Journal of Marketing Management, Vol. 31 No. 7-8, pp. 774-806.

Bowden, J.L. (2009), "The Process of Customer Engagement: A Conceptual Framework", Journal of Marketing Theory and Practice, Vol. 17 No. 1, pp. 63-74.

Bowden, J.L et al. (2017), "Engagement valence duality and spillover effects in online brnad communities. Journal of Service Theory and Practice, Vol. 27 No. 4, pp. 877-897.

Breidbach, C.F., Brodie, R. and Hollebeek, L. (2014), "Beyond virtuality: from engagement platforms to engagement ecosystems", Managing Service Quality: An International Journal, Vol. 24 No. 6, pp. 592-611.

Bridges, E. and Florsheim, R. (2008), "Hedonic and utilitarian shopping goals: The online experience", Journal of Business Research, Vol. 61 No. 4, pp. 309-314.

Brodie, R.J., Hollebeek, L.D., Juric, B. and Ilic, A. (2011a), "Customer Engagement: Conceptual Domain, Fundamental Propositions, and Implications for Research" Journal of Service Research, Vol. 14 No. 3, pp. 252-271.

Brodie, R.J., Ilic, A., Juric, B. and Hollebeek, L. (2011b), "Consumer engagement in a virtual brand community: An exploratory analysis", Journal of Business Research, Vol. 66 No. 1, pp. 105-114.

Bryman, A. (2016), Social research methods, 5th ed, Oxford University Press, Oxford.

Brynjolfsson, E., Hu, Y.J. and Rahman, M.S. (2013) "Competing in the age of omnichannel retailing", MIT Sloan Management Review, Cambridge, MA.

Chen, S. and Chang, T. (2003), "A descriptive model of online shopping process: some empirical results", International Journal of Service Industry Management. Vol. 14 No. 5, pp. 556-569.

Childers, T.L., Carr, C.L., Peck, J. and Carson, S. (2001), "Hedonic and utilitarian motivations for online retail shopping behavior", Journal of Retailing, Vol. 77 No. 4, pp. 511535.

Claffey, E. and Brady, M. (2014), "A model of consumer engagement in a virtual customer environment", Journal of Customer Behaviour, Vol. 13 No. 4, pp. 325-346. 
Demangeot, C. and Broderick, A.J. (2007), "Conceptualising consumer behaviour in online shopping environments", International Journal of Retail \& Distribution Management, Vol. 35 No. 11, pp. 878-894.

Demangeot, C. and Broderick, A.J. (2016), "Engaging customers during a website visit: a model of website customer engagement", International Journal of Retail \& Distribution Management, Vol. 44 No. 8, pp. 814-839.

Dessart, L. (2017). "Social media engagement: a model of antecedents and relational outcomes. Journal of Marketing Management, Vol. 33 No. 5-6, pp. 375-399.

Dessart, L., Veloutsou, C. and Morgan-Thomas, A. (2016), "Capturing consumer engagement: duality, dimensionality and measurement", Journal of Marketing Management. Vol. 32 No. 5-6, pp. 399-426.

Dessart, L., Veloutsou, C. and Morgan-Thomas, A. (2015), "Consumer engagement in online brand communities: a social media perspective", The Journal of Product and Brand Management, Vol. 24 No.1, pp. 28.

Doherty, N.F. and Ellis-Chadwick, F. (2009), "Exploring the drivers, scope and perceived success of e-commerce strategies in the UK retail sector", European Journal of Marketing, Vol. 43 No. 9/10, pp. 1246-1262.

Doherty, N.F. and Ellis-Chadwick, F. (2010), "Internet retailing: the past, the present and the future", International Journal of Retail \& Distribution Management. Vol. 38 No. 11, pp. 943965.

Dolan, R., Conduit, J. and Fahy, J. (2016), "Social media engagement: a construct of positively and negatively valenced engagement behaviours", in Brodie, R.J., Hollebeek, L.D. and Conduit, J. (Ed.), Customer Engagement: Contemporary issues and challenges, Routledge, Abington, Oxon, pp. 102-123.

Dwivedi, A. (2015), "A higher-order model of consumer brand engagement and its impact on loyalty intentions", Journal of Retailing and Consumer Services. Vol. 24, pp. 100-109.

Eroglu, S.A., Machleit, K.A. and Davis, L.M. (2003), "Empirical testing of a model of online store atmospherics and shopper responses", Psychology \& Marketing, Vol. 20 No. 2, pp. 139150.

Fehrer, J., Germelmann, C. and Brodie, R. (2018), "Dynamics and drivers of customer engagement: within the dyad and beyond", Journal of Service Management, Vol. 29 No. 3, pp. 443-467.

Fill, C. (2013), Marketing communications: brands, experiences and participation, 6th ed, Pearson, Harlow.

Glaser, B.G. and Strauss, A.L. (1967), The discovery of grounded theory: strategies for qualitative research. Sociology Press.

Goldsmith, R. and Flynn, L.R. (1992), "Identifying innovators in consumer product markets", European Journal of Marketing, Vol. 26 No. 12, pp. 42-55. 
Gummerus, J., Liljander, V., Weman, E. and Pihlström, M. (2012), "Customer engagement in a Facebook brand community", Management Research Review, Vol. 35 No. 9, pp. 857-877.

Harmeling, C., Moffett, J., Arnold, M. and Carlson, B. (2018), "Toward a theory of customer engagement marketing", Journal of the Academy of Marketing Science, Vol. 45 No. 3, pp. 312-335.

Hollebeek, L.D. (2011a), "Exploring customer brand engagement: definition and themes", Journal of Strategic Marketing, Vol. 19 No. 7, pp. 555-573.

Hollebeek, L.D. (2013), "The customer engagement/value interface: An exploratory investigation", Australasian Marketing Journal, Vol. 21 No.1, pp. 17-24.

Hollebeek, L.D. (2011b), "Demystifying customer brand engagement: Exploring the loyalty nexus", Journal of Marketing Management, Vol. 27 No. 7, pp. 785-807.

Hollebeek, L.D., Glynn, M.S. and Brodie, R.J. (2014), "Consumer Brand Engagement in Social Media: Conceptualization, Scale Development and Validation", Journal of Interactive Marketing, Vol. 28 No. 2, pp. 149-165.

Hollebeek, L.D., Srivastava, R.K. and Chen, T. (2016), "S-D logic-informed customer engagement: integrative framework, revised fundamental propositions, and application to CRM", Journal of the Academy of Marketing Science.

Hollebeek, L.D. and Chen, T. (2014), "Exploring positively- versus negatively-valenced brand engagement: a conceptual model", Journal of Product \& Brand Management, Vol. 23 No. 1, pp. 62-74.

Hou, F., Li, B., Chong, A.Y., Yannopoulou, N. and Liu, M.J. (2017), "Understanding and predicting what influence online product sales? A neural network approach", Production Planning \& Control, Vol. 28 No. 3, pp. 225-236.

Hsieh, J., Hsieh, Y., Chiu, H. and Yang, Y. (2014), "Customer response to web site atmospherics: Task-relevant cues, situational involvement and PAD", Journal of Interactive Marketing, Vol. 28 No. 3, pp. 225-236.

Huang, M. (2003), "Designing website attributes to induce experiential encounters", Computers in Human Behavior, Vol. 19 No. 4, pp. 425-442.

Hyder, A. and Bigné, E. (2016), "Website engagement", in Brodie, R.J., Hollebeek, L.D. and Conduit, J. (Ed.), Customer Engagement: Contemporary issues and challenges, Routledge, Abington, Oxon, pp. 152-168.

Islam, J.U. and Rahman, Z. (2017), "The impact of online brand community characteristics on customer engagement: An application of the Stimulus-Organism-Response paradigm", Telematics and Informatics, Vol. 34 No. 4, pp. 96-109.

Islam, J.U. and Rahman, Z. (2016), "The transpiring journey of customer engagement research in marketing: A systematic review of the past decade", Management Decision, Vol. 54 No. 8 , pp. 2008-2034.

Islam, J.U., Rahman, Z. and Hollebeek, L.D. (2018), "Consumer engagement in online brand communities: a solicitation of congruity theory", Internet Research, Vol. 28 No. 1, pp. 23-45. 
Jaakkola, E. and Alexander, M. (2014), "The Role of Customer Engagement Behavior in Value Co-Creation: A Service System Perspective", Journal of Service Research, Vol. 17 No. 3, pp. 247-261.

Kim, M. and Lennon, S. (2008), "The effects of visual and verbal information on attitudes and purchase intentions in internet shopping." Psychology \& Marketing, Vol. 25 No. 2, pp. 147-178.

Kim, S. and Eastin, M.S. (2011), "Hedonic tendencies and the online consumer: an investigation of the online shopping process", Journal of Internet Commerce, Vol. 10 No. 1, pp. 68-90.

Kim, J. and Lennon, S.J. (2010), "Information available on a web site: effects on consumers' shopping outcomes", Journal of Fashion Marketing and Management: An International Journal, Vol. 14 No. 2, pp. 247-262.

Koo, D. and Ju, S. (2010), "The interactional effects of atmospherics and perceptual curiosity on emotions and online shopping intention", Computers in Human Behavior, Vol. 26 No. 3, pp. 377-388.

Kumar, V., Aksoy, L., Donkers, B., Venkatesan, R., Wiesel, T. and Tillmanns, S. (2010a), "Undervalued or Overvalued Customers: Capturing Total Customer Engagement Value", Journal of Service Research, Vol. 13 No. 3, pp. 297-310.

Kumar, V., Petersen, J.A. and Leone, R.P. (2010b), "Driving Profitability by Encouraging Customer Referrals: Who, When, and How", Journal of Marketing, Vol. 74 No. 5, pp. 1-17.

Lian, J. and Yen, D.C. (2014), "Online shopping drivers and barriers for older adults: Age and gender differences", Computers in Human Behavior, Vol. 37, pp. 133-143.

Maslowska, E., Malthouse, E.C. and Collinger, T. (2016), "The customer engagement ecosystem", Journal of Marketing Management, Vol. 32 No. 5-6, pp. 469-501.

Mehrabian, A. and Russell, J.A. (1974), An approach to environmental psychology. M.I.T. Press, Cambridge, MA.

Melewar, T.C., Foroudi, P., Gupta, S., Kitchen, P.J. and Foroudi, M.M. (2017), "Integrating identity, strategy and communications for trust, loyalty and commitment", European Journal of Marketing, Vol. 51 No. 3, pp. 572-604.

Mintel. (2018), "Online Retailing - UK - July 2018", available at: http://academic.mintel.com.gcu.idm.oclc.org/display/859337/\# (accessed $21^{\text {st }}$ November 2018).

Mintel. (2017), "Fashion Online - UK - June 2017", available at: http://academic.mintel.com/homepages/rps/main/\#12 21902_201601_1_1_ 0; (accessed 30 June 2017).

Mintel. (2016), "Womenswear - UK - May 2016", available at: http://academic.mintel.com/homepages/rps/main/\#12_21902 201601_1_1 0 (accessed 14 July 2016). 
Mollen, A. and Wilson, H. (2010), "Engagement, telepresence and interactivity in online consumer experience: Reconciling scholastic and managerial perspectives", Journal of Business Research, Vol. 63 No. 9, pp. 919-925.

ONS. (2018), "Retail Sales, Great Britain: May 2018”, Office for National Statistics, available at:

https://www.ons.gov.uk/businessindustryandtrade/retailindustry/bulletins/retailsales/may2018 (accessed 28 June 2018).

Patterson, P., Yu, T. and De Ruyter, K. (2006), "Understanding Customer Engagement in Services", in Australia-New Zealand Marketing Academy Conference in Brisbane, Australia, 2006.

Sashi, C.M. (2012), "Customer engagement, buyer-seller relationships, and social media", Management Decision. Vol. 50 No. 2, pp. 253-272.

Solomon, M. (2016), "Going above and beyond customer service to achieve true customer engagement", Forbes, available at:

http://www.forbes.com/sites/micahsolomon/2016/01/04/going-beyond-customer-service-toachieve-customer-engagement/\#673e4769312e (accessed 11 July 2016).

Solomon, M.R., Bamossy, G.J., Askegaard, S.T. and Hogg, M.K. (2016). Consumer behaviour: a European perspective, 6th ed, Pearson, New York.

Sprott, D., Czellar, S. and Spangenberg, E. (2009), "The importance of a general measure of brand engagement on market behavior: Development and validation of a scale", Journal of Marketing Research. Vol. 46 No. 1, pp. 92-104.

Statista. (2014), "Global consumer interactions with retail brands on social media as of September 2014, by age", Statista, available at:

https://www.statista.com/statistics/411895/consumer-social-media-interactions-with-brandsage/ (accessed 30 June 2018).

Underhill, P. (1999), Why we buy: the science of shopping, Texere, London.

Van Doorn, J., Lemon, K.N., Mittal, V., Nass, S., Pick, D., Pirner, P. and Verhoef, P.C. (2010), "Customer Engagement Behavior: Theoretical Foundations and Research Directions" Journal of Service Research, Vol. 13 No. 3, pp. 253-266.

Vargo, S.L. and Lusch, R.F. (2008), "Service-dominant logic: continuing the evolution", Journal of the Academy of Marketing Science, Vol. 36 No. 1, pp. 1-10.

Vargo, S.L. and Lusch, R.F. (2004), "Evolving to a New Dominant Logic for Marketing", Journal of Marketing, Vol. 68 No. 1, pp. 1-17.

Verhoef, P.C., Kannan, P.K. and Inman, J.J. (2015), "From multi-channel retailing to omnichannel retailing: Introduction to the special issue on multi-channel retailing", Journal of Retailing, Vol. 91 No.2, pp. 174-181.

Vivek, S.D., Beatty, S.E. and Morgan, R.M. (2012), "Customer Engagement: Exploring Customer Relationships Beyond Purchase", Journal of Marketing Theory and Practice, Vol. 20 No. 2, pp. 122-146. 
Wolfinbarger, M. and Gilly, M.C. (2001), "Shopping online for freedom, control, and fun", California Management Review, Vol. 43 No. 2, pp. 34-55.

Wu, W., Lee, C., Fu, C. and Wang, H. (2014), "How can online store layout design and atmosphere influence consumer shopping intention on a website?", International Journal of Retail \& Distribution Management, Vol. 42 No. 1, pp. 4-24. 
Relationship Marketing

Bowden (2009)

\begin{tabular}{|c|c|c|c|c|}
\hline Bowden (2009) & Relationship Marketing & Service brand & Conceptual & \\
\hline Hollebeek (2011b) & Relationship Marketing & Brand & Conceptual & \\
\hline Sashi (2012) & Relationship Marketing & Brand & Conceptual & $\begin{array}{l}\text { Commitment-trust } \\
\text { theory }\end{array}$ \\
\hline Vivek et al. (2012) & Relationship Marketing & $\begin{array}{l}\text { Organisational } \\
\text { offering or activities }\end{array}$ & $\begin{array}{l}\text { Empirical } \\
\text { qualitative }\end{array}$ & \\
\hline Dessart et al. (2016) & Relationship Marketing & $\begin{array}{l}\text { Online brand } \\
\text { communities }\end{array}$ & $\begin{array}{l}\text { Empirical } \\
\text { qualitative } \\
\text { followed by } \\
\text { quantitative }\end{array}$ & \\
\hline Beckers et al. (2016) & Relationship Marketing & $\begin{array}{l}\text { Online brand } \\
\text { communities/social } \\
\text { media }\end{array}$ & Conceptual & $\begin{array}{l}\text { Transaction cost } \\
\text { economies; The } \\
\text { resource-based } \\
\text { view; Social } \\
\text { exchange theory }\end{array}$ \\
\hline $\begin{array}{l}\text { Dessart et al. } \\
(2017)\end{array}$ & Relationship Marketing & $\begin{array}{l}\text { Online brand } \\
\text { communities }\end{array}$ & $\begin{array}{l}\text { Empirical } \\
\text { quantitative }\end{array}$ & \\
\hline
\end{tabular}

Relationship Marketing communities

quantitative

\section{Relationship Marketing and Service Dominant (S-D) logic}

\begin{tabular}{|c|c|c|c|c|}
\hline $\begin{array}{l}\text { Brodie et al. } \\
(2011 \mathrm{a})\end{array}$ & $\begin{array}{l}\text { Relationship marketing } \\
\text { and Service Dominant } \\
\text { (S-D) logic }\end{array}$ & Brand & Conceptual & S-D Logic \\
\hline Hollebeek (2011a) & $\begin{array}{l}\text { Relationship marketing } \\
\text { and Service Dominant } \\
\text { (S-D) logic }\end{array}$ & Brand & $\begin{array}{l}\text { Empirical } \\
\text { qualitative }\end{array}$ & $\begin{array}{l}\text { Social exchange } \\
\text { theory }\end{array}$ \\
\hline Brodie et al. (2011b) & $\begin{array}{l}\text { Relationship marketing } \\
\text { and Service Dominant } \\
\text { (S-D) logic }\end{array}$ & $\begin{array}{l}\text { Online brand } \\
\text { communities }\end{array}$ & $\begin{array}{l}\text { Empirical } \\
\text { qualitative }\end{array}$ & S-D Logic \\
\hline Vivek et al. (2014) & $\begin{array}{l}\text { Relationship marketing } \\
\text { and Service Dominant } \\
\text { (S-D) logic }\end{array}$ & $\begin{array}{l}\text { Brand, organisational } \\
\text { offering or activities }\end{array}$ & $\begin{array}{l}\text { Empirical } \\
\text { qualitative } \\
\text { followed by } \\
\text { quantitative } \\
\end{array}$ & S-D Logic \\
\hline $\begin{array}{l}\text { Dessart et al. } \\
(2015)\end{array}$ & $\begin{array}{l}\text { Relationship marketing } \\
\text { and Service Dominant } \\
\text { (S-D) logic }\end{array}$ & $\begin{array}{l}\text { Online brand } \\
\text { communities }\end{array}$ & $\begin{array}{l}\text { Empirical } \\
\text { qualitative }\end{array}$ & \\
\hline \multicolumn{5}{|c|}{ Service Dominant (S-D) logic } \\
\hline $\begin{array}{l}\text { Breidbach et al. } \\
(2014)\end{array}$ & $\begin{array}{l}\text { Service Dominant (S-D) } \\
\text { logic }\end{array}$ & $\begin{array}{l}\text { Engagement } \\
\text { platforms }\end{array}$ & Conceptual & \\
\hline $\begin{array}{l}\text { Hollebeek et al. } \\
(2016)\end{array}$ & $\begin{array}{l}\text { Service Dominant (S-D) } \\
\text { logic }\end{array}$ & $\begin{array}{l}\text { Customer } \\
\text { Relationship } \\
\text { Management } \\
\end{array}$ & Conceptual & \\
\hline $\begin{array}{l}\text { Bowden et al. } \\
(2017)\end{array}$ & $\begin{array}{l}\text { Service Dominant (S-D) } \\
\text { logic }\end{array}$ & $\begin{array}{l}\text { Online brand } \\
\text { communities }\end{array}$ & $\begin{array}{l}\text { Empirical } \\
\text { qualitative }\end{array}$ & \\
\hline
\end{tabular}

Consumer Behaviour

\begin{tabular}{|c|c|c|c|c|}
\hline Calder et al. (2009) & Consumer behaviour & $\begin{array}{l}\text { Media context } \\
\text { (website) }\end{array}$ & $\begin{array}{l}\text { Empirical } \\
\text { quantitative }\end{array}$ & $\begin{array}{l}\text { Uses and } \\
\text { gratifications } \\
\text { theory }\end{array}$ \\
\hline $\begin{array}{l}\text { Mollen \& Wilson } \\
(2010)\end{array}$ & Consumer behaviour & $\begin{array}{l}\text { Brand personified by } \\
\text { the website }\end{array}$ & Conceptual & $\begin{array}{l}\text { Stimulus Organism } \\
\text { Response (S-O-R) } \\
\text { model }\end{array}$ \\
\hline $\begin{array}{l}\text { Kumar et al. } \\
(2010 \mathrm{a})\end{array}$ & Consumer behaviour & Brand/organisation & Conceptual & \\
\hline $\begin{array}{l}\text { van Doorn et al. } \\
(2010)\end{array}$ & Consumer behaviour & Brand & Conceptual & \\
\hline $\begin{array}{l}\text { Gummerus et al. } \\
\text { (2012) }\end{array}$ & Consumer behaviour & $\begin{array}{l}\text { Online gaming } \\
\text { community }\end{array}$ & $\begin{array}{l}\text { Empirical } \\
\text { quantitative }\end{array}$ & \\
\hline $\begin{array}{l}\text { Claffey \& Brady } \\
(2014)\end{array}$ & Consumer behaviour & $\begin{array}{l}\text { Virtual customer } \\
\text { environment (social } \\
\text { media) }\end{array}$ & $\begin{array}{l}\text { Empirical } \\
\text { quantitative }\end{array}$ & $\begin{array}{l}\text { Stimulus Organism } \\
\text { Response (S-O-R) } \\
\text { model }\end{array}$ \\
\hline Bitter et al. (2014) & Consumer behaviour & Social media & $\begin{array}{l}\text { Empirical } \\
\text { quantitative }\end{array}$ & $\begin{array}{l}\text { Theory of planned } \\
\text { behaviour \& Social } \\
\text { practice theory }\end{array}$ \\
\hline Dolan et al. (2016) & Consumer behaviour & Social media & Conceptual & \\
\hline
\end{tabular}




\begin{tabular}{|c|c|c|c|c|}
\hline Islam et al. (2018) & Consumer behaviour & $\begin{array}{l}\text { Online brand } \\
\text { communities }\end{array}$ & $\begin{array}{l}\text { Empirical } \\
\text { quantitative }\end{array}$ & $\begin{array}{l}\text { Congruity theory: } \\
\text { self congruity/ } \\
\text { value congruity }\end{array}$ \\
\hline \multicolumn{5}{|l|}{ Dual Perspectives } \\
\hline $\begin{array}{l}\text { Demangeot \& } \\
\text { Broderick (2016) }\end{array}$ & $\begin{array}{l}\text { Relationship marketing } \\
\text { and marketing } \\
\text { communications }\end{array}$ & $\begin{array}{l}\text { Website } \\
\text { (transactional: books) }\end{array}$ & $\begin{array}{l}\text { Empirical } \\
\text { quantitative }\end{array}$ & \\
\hline $\begin{array}{l}\text { Maslowska et al. } \\
(2016)\end{array}$ & $\begin{array}{l}\text { Service marketing and } \\
\text { consumer behaviour }\end{array}$ & Brand & Conceptual & $\begin{array}{l}\text { Uses and } \\
\text { gratifications } \\
\text { theory; Elaboration } \\
\text { Likelihood model }\end{array}$ \\
\hline \multicolumn{5}{|l|}{ Technological } \\
\hline $\begin{array}{l}\text { Hyder \& Bigné } \\
\text { (2016) }\end{array}$ & $\begin{array}{l}\text { Technological } \\
\text { engagement }\end{array}$ & $\begin{array}{l}\text { Website } \\
\text { (transactional: travel) }\end{array}$ & $\begin{array}{l}\text { Empirical } \\
\text { quantitative }\end{array}$ & \\
\hline
\end{tabular}

Table I: Theoretical perspectives through which customer engagement has been studied 


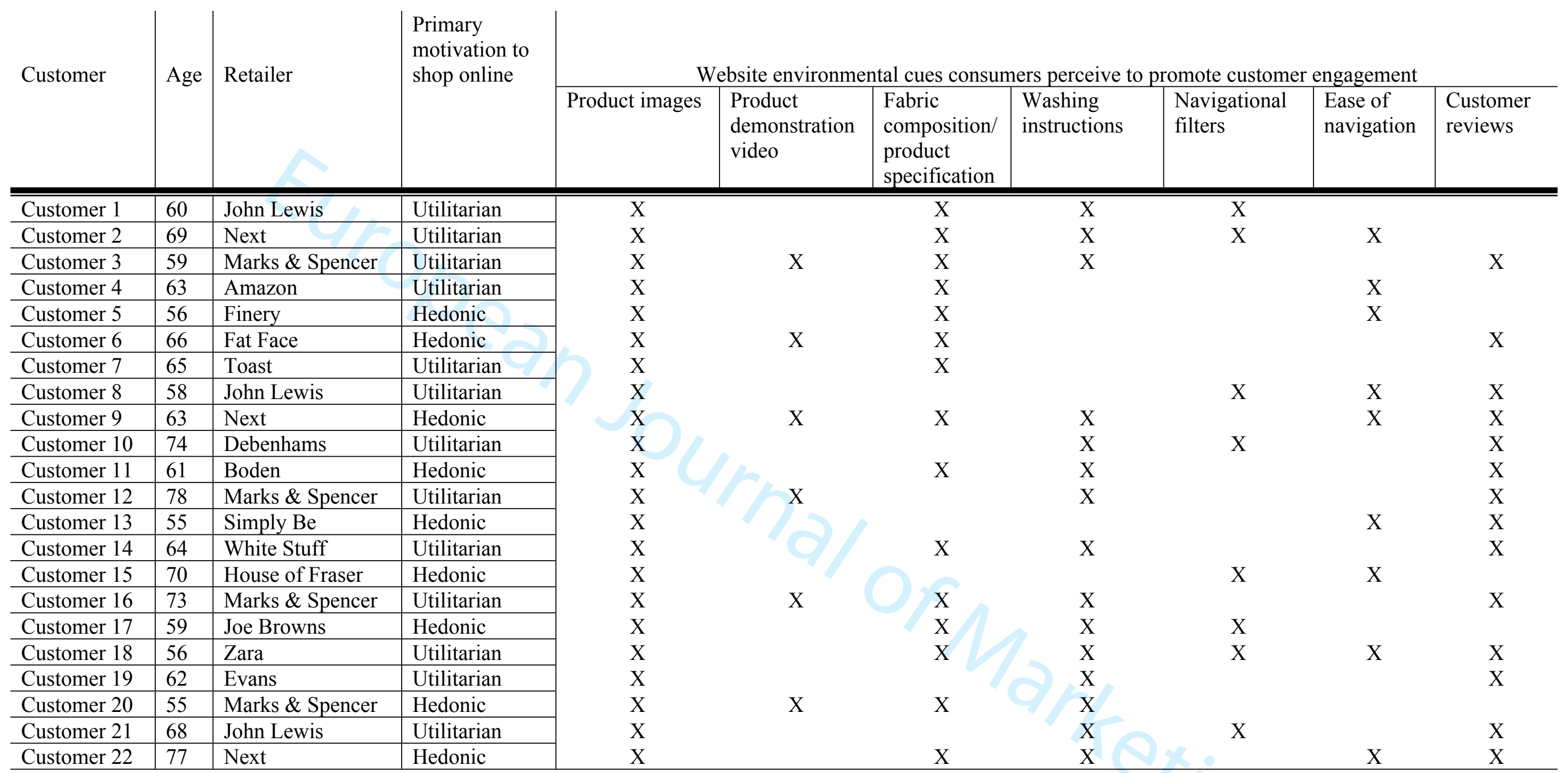

Table II: Website environmental cues identified as stimulating customer engagement 


\begin{tabular}{|c|c|c|c|c|}
\hline \multirow[b]{2}{*}{ Cue } & \multicolumn{2}{|c|}{ Hedonically-motivated customer } & \multicolumn{2}{|c|}{ Utilitarian-motivated customer } \\
\hline & Cognitive & Affective & Cognitive & Affective \\
\hline $\begin{array}{l}\text { Product } \\
\text { images }\end{array}$ & $\begin{array}{l}\text { "Once I've seen an item I like I } \\
\text { think about how it will look on me. } \\
\text { Whether it will suit me. What else } \\
\text { I already have that I can wear with } \\
\text { it." (Customer 5) }\end{array}$ & $\begin{array}{l}\text { "I like certain colours and } \\
\text { shapes and when I see those I } \\
\text { can't help myself but click on } \\
\text { the picture to look further." } \\
\text { (Customer 9) }\end{array}$ & $\begin{array}{l}\text { "If I am looking for something } \\
\text { that is it; I will keep searching } \\
\text { until I find it, all night if I have } \\
\text { to." (Customer 14) }\end{array}$ & $\begin{array}{l}\text { "I do get that feeling when I } \\
\text { find something I really like, you } \\
\text { know, you think, 'jackpot!"” } \\
\text { (Customer 19) }\end{array}$ \\
\hline $\begin{array}{l}\text { Washing } \\
\text { instructions }\end{array}$ & $\begin{array}{l}\text { "I always study the washing } \\
\text { instructions. Everything has to go } \\
\text { in the washing machine and } \\
\text { preferably the tumble dryer. I } \\
\text { won't buy anything that is dry } \\
\text { clean only." (Customer 9) }\end{array}$ & & $\begin{array}{l}\text { "I pay attention to it definitely. I } \\
\text { don't want to keep having to pay } \\
\text { to get the thing dry cleaned." } \\
\text { (Customer 18) }\end{array}$ & \\
\hline
\end{tabular}




\begin{tabular}{l|l|l||l|l|}
\hline $\begin{array}{l}\text { Navigational } \\
\text { filters }\end{array}$ & $\begin{array}{l}\text { "On sites where they have } \\
\text { hundreds and hundreds of items } \\
\text { they really stop me getting fed up } \\
\text { because I can just narrow it down } \\
\text { to the things that I know I'll like or } \\
\text { that they definitely have in my } \\
\text { size." (Customer 11) }\end{array}$ & & $\begin{array}{l}\text { "I use them. I use garment type. I } \\
\text { use size. I use colour. It cuts } \\
\text { down on having to look at a load } \\
\text { of things that you will never } \\
\text { buy." (Customer 1) }\end{array}$ & \\
\hline $\begin{array}{l}\text { Ease of } \\
\text { navigation }\end{array}$ & & $\begin{array}{l}\text { "I feel a bit stupid when I can't } \\
\text { find things or get a bit lost. I'm } \\
\text { not brilliant with computers, I } \\
\text { do try, but I'm not all that } \\
\text { competent." (Customer 22) }\end{array}$ & & $\begin{array}{l}\text { "If I'm on a website and it's } \\
\text { difficult to use: it's slow or } \\
\text { clunky or confusing, I leave. I } \\
\text { don't have time for that." } \\
\text { (Customer 1) }\end{array}$ \\
\hline $\begin{array}{l}\text { Customer } \\
\text { reviews }\end{array}$ & $\begin{array}{l}\text { "I do look but I don't always listen } \\
\text { to them. I will take a judgement on } \\
\text { whether to go ahead and order the } \\
\text { thing anyway - especially if I } \\
\text { really like it." (Customer 6) }\end{array}$ & & $\begin{array}{l}\text { "Any negative comments about } \\
\text { the fabric or fit really put me off } \\
\text { buying. I read the reviews quite } \\
\text { carefully actually." (Customer } \\
\text { 10) }\end{array}$ &
\end{tabular}

Table III: Illustrative quotes - facets of positive cognitive and affective responses to website environmental cues

*Arrows denote the direction of engagement between cognitive and affective dimensions when both are stimulated 